\title{
KINERJA CT DALAM MENDETEKSI TRAUMA USUS BESAR
}

\author{
I Gusti Ngurah Ariwangsa Asbita \\ Program Studi Pendidikan Dokter, Fakultas Kedokteran, Universitas Udayana \\ aabita@gmail.com
}

\section{ABSTRAK}

Relevansi dan reliabilitas gambaran CT pada trauma usus besar, sangat menentukan kemampuan CT dalam mendeteksi trauma usus dan mencari pengaruh tingkat pendidikan ahli radiologi terhadap kemampuan CT.112 CT scan abdomen pada pasien dengan trauma tumpul abdomen yang diikuti secara prospektif dan retrospektif . 50 pasien terbukti trauma usus (dengan atau tanpa trauma organ lain), sedangkan 62 pasien tidak terbukti trauma injuri usus dibandingkan dengan kelompok kontrol. 31 dari 62 pasien pada kelompok kontrol mengalami pembedahan abdomen tetapi bukan trauma mesenterik. Peninjauan secara retrspektif pada 112 CT scan telah diacak oleh sembilan ahli radiologi tanpa melihat diagnosis, termasuk tiga stap pengajar ahli radiologis, tiga residen senior, tiga residen junior. Kemampuan individual dan grup telah dievaluasi. Gambaran sebuah CT sebagai prediktor yang relevan dari trauma usus telah diidentivikasi dengan regresi logistik.Prediktor yaag relevan pada tauma usus besar termasuk infitrasi mesenterik, penebalan diding usus, extravasasi pembuluh darah atau bahan contraha enterik dan adanya udara bebas. Pada peninjauan retrospectif blinded, CT bagus untuk diagnosis trauma usus besar dan trauma viscera. Stap pengajar radiologi cenderung lebih akurat dalam mendiagnosis trauma dibandingkan residen. Untuk prospektif CT dalam mendignosis trauma usus, CT mempunyai sensitivitas $64 \%$, akurasi $82 \%$ dan spesifisitas $97 \%$.

Trauma usus besar hádala tantangan untuk didiagnosis dengan CT. Ahli radiologi dengan tingkat pengalaman dan keahlian yang berbeda dapat mencapai hasil yang akurat menggunakan kriteria CT.

\section{PENDAHULUAN}

Trauma abdominal masih menjadi penyebab kematian dan kecacatan yang paling sering, yaitu sekitar $10 \%$ dari seluruh kasus trauma di Amerika Serikat.Sebanyak $5 \%$ dari seluruh trauma tumpul merupakan trauma usus dan mesenterikyang diketahui melaluilaparotomi dan sulit diketahuisebelum operasi. Meskipun gejala klinis dari nyeri perut dan peritonitis yang berat dan lavage yang memberikan hasil positifterdapat pada kasus-kasus trauma usus yang berat, tes-tes ini tidak bersifat diagnostik pada kebanyakan pasien ketika awal masuk rumah sakit. Lavage peritoneal sering tidak dapat mengetahuiadanya sumber perdarahan abdominal atau trauma usus retroperitoneal pada kebanyakan pasien. Diagnosa trauma usus yang terlambat dapat meningkatkan angka kesakitan dan angka kematian.

CT merupakan pencitraan yang akuratuntuk menggambarkan trauma pada organ abdomen yang padat.Akan tetapi, keakuratan CT untukmenilaitrauma usus dan mesenterikmasih kontroversi, seperti yang dilaporkan oleh beberapa pihak yang menyatakan bahwa CT sama sekali tidak akurat untuk mendiagnosa, sedangkan yang lainnya,menyatakanbahwa CT sangat akurat dan bermanfaat. Selama 10 tahun terakhir, pertanda CT pada kasustrauma usus dan mesenteriktelah dijabarkan dalam berbagai penelitian retrospektif dan ditujukan untuk analisis diagnostik yang sifatnya terbatas.

Penjelasan-penjelasan yang logis berkenaan dengan perbedaanyang sangat jauh dari kinerja CT adalah adanya perbedaan di dalam pengaturannya, yaitu variasi-variasi peralatan CT atau teknik-tekniknya, tingkat keahlian interpreter CT, dan kemampuan individu. Tujuan dari studi ini adalah untukmenentukan relevansi dan reliabilits CT dalam mendeteksi trauma usus serta mesenterik.

\section{METODE PENELITIAN}

Sebanyak 13.963 pasien dengan trauma tumpul abdominal dievaluasi dan ditangani di pusat trauma tingkat I mulai Juni 1990 hingga November 1977. Melalui tinjauan ulang radiologi dan data 
pencatatan trauma didapatkan 54 pasien yang menjalani CTabdomen pada awal evaluasinya. Film CT pada penelitian ini tersedia untuk 50 dari 54 pasien ini. Sebanyak 62 pasien trauma tambahan lagi yang dipilih secara acak juga menjalanievaluasi dengan CT; 62 pasien ini dimasukkan ke dalam kelompok pembanding. Selama periode studi yang sama, 121 pasien dengan trauma tumpul pada usus menjalani pembedahan, tetapi CT preoperasi tidak dilaksanakan karena beratnya trauma.

Didapatkan112 pasien yang terdiri dari 73 laki-laki dan 39 wanita dengan usia dari 14 sampai 86 tahun (nilai-tengah 38 tahun; median 33 tahun). Sebanyak 50 pasien yang terbukti mangalami trauma usus dan mesenterikdikonfirmasi dengan pembedahan perut $(n=48)$ atau dengan barium in-take ( 2 pasien dengan hematom duodenal).

Kelompok pembanding terdiri atas 31 pasien yang menjalanilaparotomi dan menunjukkan berbagai trauma padaorgan viseral abdomen dan perdarahantetapi tidak termasuktrauma usus atau mesenterik, dan 31 pasien yang tidak menjalani operasi serta tidak mempunyai keluhan di perut setidaknya sampai 2 minggu keluar dari rumah sakit. Meskipun kasus pada kelompok pembanding dipilih secara acak, kamitelah memasukkan beberapa pasien yang tidak mengalami kelainan paska trauma dan kelompok yang dapat mewakili studi CT dengan berbagai trauma organ viseral sehingga dapat mendekati keadaan yang sebenarnya. Karena trauma usus tidak jarang terjadi, observer yang dibutakan diperlukan untuk menginterpretasikan dan menilai ratusan hasil CT scan. Dari 50 pasien dengan trauma usus atau mesentrik yang benarbenar terbukti, 22 pasien tidak mengalami trauma lain. Sisanya, 28 pasien mengalami trauma pada usus dan organ viseral lainnya, termasuk trauma pada limpa $(n=17)$, hati $(n=9)$, ginjal ( $n$ $=3$ ), pankreas ( $n=2)$, dan kandung kemih ( $n=2$ ). Kelompok tanpa trauma usus yang telah dieksplorasi dengan pembedahan terdiri dari 6 orang pasien dan 25 orang yang hanya mengalami trauma viseral, termassuk trauma pada limpa ( $\mathrm{n}$ $=18)$, hati $(n=6)$, ginjal $(n=2)$, dan pankreas $(n=2)$. Kelompok pasien yang ditangani tanpa pembedahan meliputi 20 orang pasien tanpa trauma abdomen dan trauma pada satu atau lebih organ viseral, termasuk trauma pada hati $(n=7)$, limpa $(n=4)$, ginjal $(n=1)$, dan kelenjar adrenal ( $n$ $=1$ ).

Semua pasien menjalani CT abdominopelvis ketika dievaluasi di IRD. Kontras melalui parenteral dan oral digunakan untuk membantu diagnosa.Sekitar 95\% dari semua studi dilaksanakan dengan menggunakan kedua kontras, baik parenteral maupun oral. Kontras parenteral yang dipakai adalah iothalamate meglumine atau ioversol (Conray60 atau Optiray 320, Mallinckrodt Medical, St. Louis, MO) dengan volume $2 \mathrm{~mL} / \mathrm{kgBB}$ dengan dosis maksimum $150 \mathrm{~mL}$ dan kecepatannya $25 \mathrm{~mL} /$ detik. Sedangkan kontras peroral yang dipakai adalah diatrizoate meglumine dan sodium yang dilarutkan dengan air (dengan rasio 1:40). Pasienyang sadar minum $450 \mathrm{~mL}$ larutan 2,5\% tadi, sedangkan pada pasien dengan penurunan kesadaran digunakan pipa nasogastrik. Kontras peroral segera diberikan sesaat sebelum CT dilakukan, sekitar 30 menit sebelumnya oleh suatu perawat di IRD.Kira-kira separuh dari kedua studi dan kelompok pembanding dievaluasi dengan menggunakan CT konvensional (nonhelikal), sedangkan sisanya menggunakan CT helikal. Untuk semua pasien dilakukan pemeriksaan dengan potongan $7 \mathrm{~mm}$ dari atas diafragma ke simfisis pubis. Untuk pasien yang kooperatif, pengambilan gambar CT non-helikal dilakukan selama menahan napas, dan CT helikaldilakukan ketika satu nafas tertahan; pemeriksaan tulang pangguldilakukan selama rangkaian yang kedua.

Pemeriksan semua hasil CT dilakukan secara retrospektif, acak, dan individualoleh 9 orang observer yang mengetahui semua informasi klinis kecuali riwayat trauma abdomen itu sendiri. Observer mengetahui bahwa kami sedang meneliti hasil diagnosa CT mengenai trauma usus, tetapi mereka tidak tahu jumlah kasus trauma usus di antara 112 pasien tersebut. Observer terdiri atas 3 radiolog abdomen fakultas, 3residen radiologi senior, dan 3 residen radiologi yunior. Semua residen tersebut sudah berpengalaman dalam memantau CT pada pasien trauma selama bertugas di rumah sakit.

Observer tersebut tidak mendapatkan pelatihan khusus hanya ditekankan akan laporan CT yang menandakan adanya trauma usus dan 
mesenterik. Masing-masing observer diminta untuk melaporkan pendapatnya dalam mendiagnosa dan mengeksklusi kasus trauma usus atau mesenterik dengan memakai suatu skala dari 0 (pasti tidak ada trauma) hingga 5 (pasti ada trauma). Dengan skala yang sama, observer mengevaluasi hasil $\mathrm{CT}$, termasuk penebalan dinding usus, peningkatan densitas dinding usus yang tidak normal, infiltrasi mesenterik,

Tabel 1. Kesamaan antar Observer : Analisis dengan Nilai Alfa Cronbach

\begin{tabular}{lc}
\hline \multicolumn{1}{c}{ Temuan/pertanda CT } & $\boldsymbol{\alpha}$ \\
\hline Trauma viseral abdomen & $\geq 0,9$ \\
Udara bebas di intraperitoneal & 0,94 \\
Infiltrasi mesenterik & 0,91 \\
Penebalan dinding usus besar & 0,90 \\
Enhancement dinding usus yang & 0,88 \\
abnormal & 0,89 \\
Cairan bebas di intraperitoneal & 0,85 \\
Ekstravasasi kontras parenteral & 0,82 \\
Ekstravasasi kontras oral-enterik & 0,71 \\
Ileus & \\
\hline
\end{tabular}

keluarnyabahan kontras baik yang ada di vaskuler atau yang di dalam usus, udara/gas di ekstralumen, ileus, dan darah intraperitoneal. Observer juga mencatat diagonosa trauma pada organ viseral lainnya (hati, limpa, pankreas atau ginjal).

Kinerja individu dan kelompok dievaluasi oleh analisa karakteristik standar (MRMC). Kesamaan hasil dianalisa Cronbach alfa, di mana nilai alfa 0,8 atau lebih besar. Pertanda CT yang individual diidentifikasi dengan menggunakan koefisien regresi.

Kami juga meninjau bahwainterpretasi CT dilakukan selama masapenelitian, baik di IRD atau di bagian radiologi. Masing-masing CT telah ditinjau oleh residen di dalam pelatihan dan 1 dari 8 radiologiabdomen fakultas.

\section{HASIL}

Langkah pertama dalam analisa adalah menentukan kesamaan hasil diagnose dan menetapkan pertanda CT yang khas untuk trauma usus. Seperti yang dilihat pada Tabel 1,kesepakatan antara observer sangatlah baik dalam mendiagnosa trauma pada organ intraperitoneal (hati, limpa atau usus), dengan nilai alfa 0,90 atau lebih besar. Nilai alfa 0,8 atau lebih besar menunjukkan bahwa hasil tersebut dapat dipercaya. Kesepakatan mengenai pertanda CT dalam menduga adanya trauma usus juga baik $(\alpha=0,82-0,94)$ kecuali untuk ileus $(\alpha=0,71)$.

Analisis regresi logistik menyatakan bahwainfiltrasi mesenterik, penebalan dinding usus,dan udara bebasdalam intraperitoneal merupakan prediktor trauma usus yang relevan. Infiltrasi mesenterik tidak hanya terlihat pada $68 \%$ pasien dengan trauma usus, tetapi juga terlihat pada $23 \%$ pasien yang mengalami trauma abdomen lainnya.Penebalan dinding usus besar terlihat pada $60 \%$ kasus trauma usus besar dan $8 \%$ trauma lainnya. Ekstravasasi bahan kontras enterik dan gas extraluminal terlihat hanya pada laserasi tranmural usus besar ( $14 \%$ dan 32\% trauma usus besar, secara retrospektif), kecuali beberapa kasus udara bebas yang terdapat setelah diagnosis peritoneal lavage. Cairan bebas peritoneal, penebalan dindind usus besar dan ileus ádalah prediktor yang kurang efektif. Gambaran CT “ada” atau "tidak " untuk memilih binary análisis.

Kemampuan CT untuk mendeteksi trauma usus besar telah dievaluasi dengan receiver operator characteristik análisis (Tabel 2). CT lebih akurat dalam mediagnosis perforasi duodenum dan perforasi usus kecil (laserasi transmural). Staf pengajar ahli radiologi cenderung mencapai akurasi lebih tinggi dibandingkan residen. Residen junior dan senior memiliki prestasi yang sebanding, meskipun prestasi individual junior residen memiliki akurasi lebih tinggi daripada individual staf pengajar. Hanya secara statistik perbedaan signifikan bisa ditentukan diantara kelompok staf pengajar radiologi yang mendiagnosis perforasi duodenum dari pada kedua kelompok residen (Gambar 4). Prestasi ketiga kelompok ahli radiologi kurang bisa mendeteksi trauma gaster dan colon (area dibawah receiver operator characteristic curve $|A z|<0,70)$ dan untuk mendeteksi hematoma jejunum dan ileum $\left(A_{z}<0,70\right)$. 

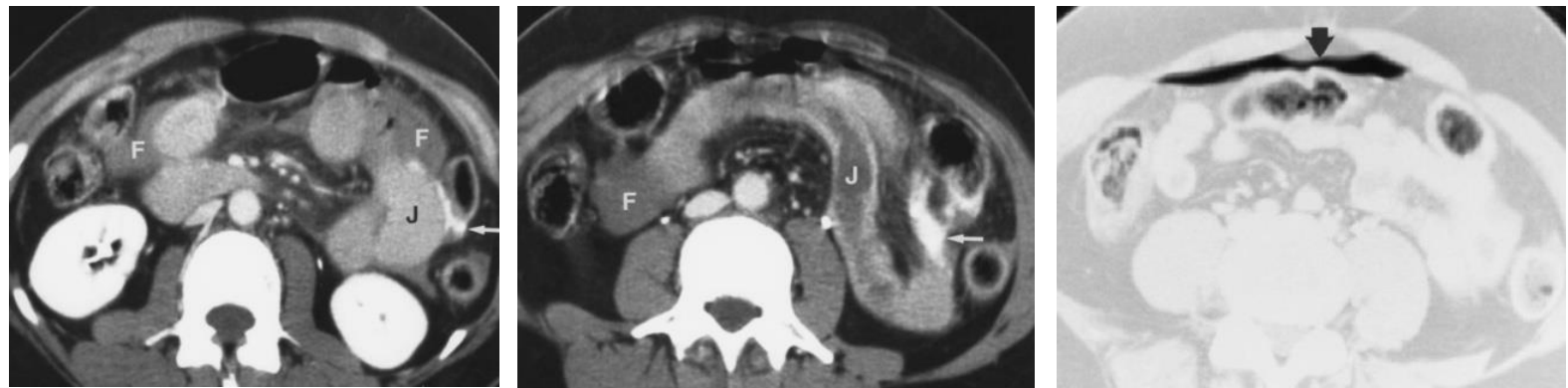

Gambar 1. Wanita, 46 tahun, mengalami laserasi jejunum disertai perdarahan aktif akibat kecelakaan yang dialaminya

Jumlah kasus true positive adalah 32 kasus (untuk diagnosis trauma usus dan trauma mesenterik); kasus false negative ,18; kasus falsepositve, 2;kasus true negative, 60. Ini diperoleh pada sensitivitas $64 \%$, spesifisitas $97 \%$, akurasi $82 \%$ untuk interpretasi prospektif.
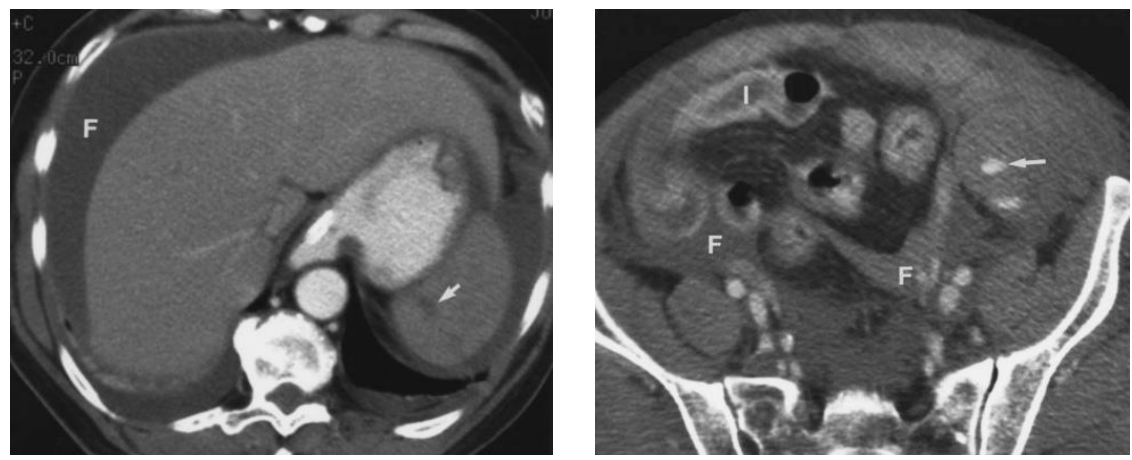

Gambar 2. Wanita, 74 tahun, yang mengalami laserasi ileum dan perdarahan mesenterik akibat kecelakaan
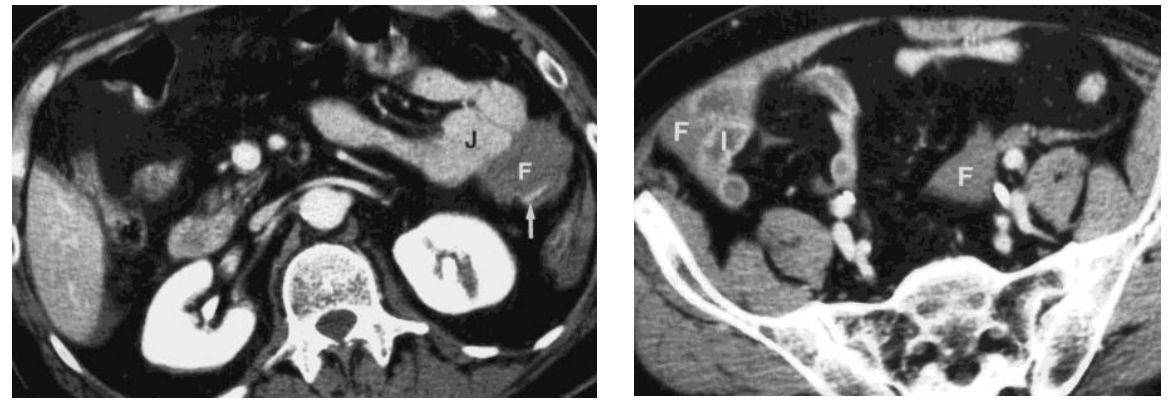

Gambar 3. Laki-laki, 65 tahun, yang mengalami perdarahan mesenterik akibat kecelakaan

\section{DISKUSI}

Walaupun secara umum CT memiliki akurasi yang tinggi dalam memperlihatkan jejas traumatis pada organ-organ solid abdomen, namun dilaporkan memperlihatkan hasil yang berlainan berhubungan dengan akurasi CT dalam memperlihatkan jejas pada usus dan mesenteri. Diantara penyebabpenyebab yang mungkin dalam ketidaksesuaian ini yaitu variasi dari peralatan dan teknik $\mathrm{CT}$, variasi didasarkan pada akurasi dari sebuah CT memperlihatkan tanda-tanda trauma usus, dan tingkat pengalaman dan keahlian dokter umum dalam menginterpretasikan hasil CT scan.
Peralalatan dan teknik CT yang digunakan dalam studi ini adalah sama dengan yang digunakan pada penelitian lain yang dilaporkan lebih dari 15 tahun. Hampir setengah dari studi didapatkan dari peralatan konvensional aksial dan setengahnya dengan peralatan CT helical. Walaupun kita mencatat bahwa tidak ada perbedaan yang signifikan pada hasil-hasil penelitian berhubungan dengan penscan helical dengan nonhelikal, kemampuan untuk mendapatkan potonganpotongan CT helical melalui keseluruhan abdomen dan pelvis selama 1-2 tahanan napas dan selama puncak kekeruhan vaskular sepertinya 
memberikan hasil yang optimal. Kemampuan untuk mengeliminasi artefak-artefak yang bergerak dan untuk menggambarkan perembesan aktif dari medium kontras vaskular adalah keuntungan utama dari CT helikal.

Tabel 2. Kinerja CT dalam mendiagnosa Trauma Usus Besar : Analisis Karakter Operator

\begin{tabular}{lcccc}
\hline \multicolumn{1}{c}{ Observers } & $\begin{array}{c}\text { Duodenal } \\
\text { hematoma }\end{array}$ & $\begin{array}{c}\text { Duodenal or tear } \\
\text { perforation }\end{array}$ & $\begin{array}{c}\text { Jejunal tear or } \\
\text { perforation }\end{array}$ & $\begin{array}{c}\text { lleal tear or } \\
\text { perforation }\end{array}$ \\
\hline Faculty radiologist & $0,71-0,86$ & $0,93-0,98$ & $0,82-0,88$ & $0,93-0,95$ \\
Senior radiologist & $0,65-0,73$ & $0,77-0,85$ & $0,61-0,85$ & $0,60-0,94$ \\
Junior radiologist & $0,78-0,83$ & $0,75-0,92$ & $0,77-0,92$ & $0,83-0,92$ \\
\hline
\end{tabular}

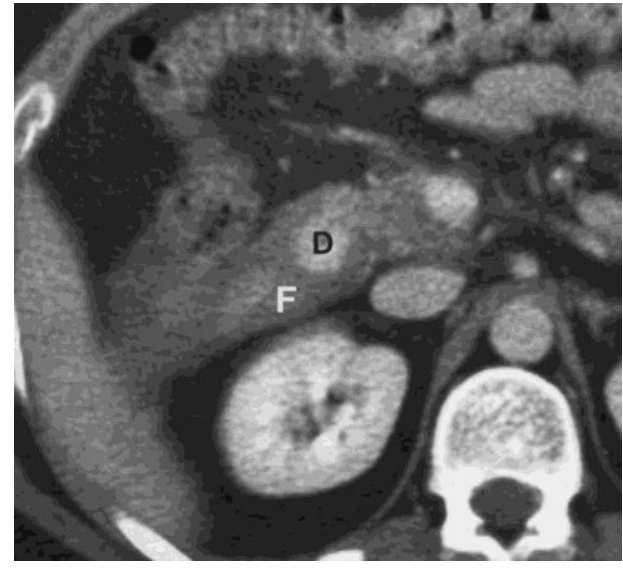

Gambar 4. Laki-laki, 33 tahun, yang mengalami laserasi duodenum akibat kecelakaan. Potongan transversal CT melalui pertengahan abdomen menunjukkan adanya cairan retroperitoneal (F) di sekitar duodenum.

Seperti ahli radiologis pada pusat-pusat trauma, kami selalu menggunakan kontras secara oral untuk CT abdomen pada pasien dengan trauma. Meskipun orang lain telah mengklaim bahwa praktek ini tidak diperlukan dan berpotensi berbahaya [11], kami percaya klaim ini memiliki validitas yang sedikit. Dalam beberapa studi khusus yang mencari bukti aspirasi pneumonitis yang berhubungan dengan penggunaan media kontras oral dalam pengaturan trauma, tidak didokumentasikan kejadian yang ditemukan pada lebih dari 1000 orang dewasa dan 50 pasien anakanak [24-26]. Walaupun kita mengidentifikasi ekstravasasi media kontras oral hanya pada tujuh (14\%) dari 50 pasien, ini merupakan tanda yang sangat spesifik dari laserasi usus transmural. Selain itu, kami percaya bahwa opasifikasi usus membuat perdarahan mural dan interloop lebih mudah dikenali (Gambar. 1).
Ekstravasasi dari media kontras mesenteric vascular juga relatif jarang tetapi tanda spesifik dari mesenteric atau cedera usus yang signifikan. Kami mendeteksi tanda ini dari pendarahan aktif pada pemeriksaan CT di 16\% (8 / 50) dari pasien dengan cedera usus atau mesenteric dan tidak ada satupun dari pasien trauma dengan cedera lainnya (Figs. 1-3). Dowe $\mathrm{dkk} .{ }^{18}$ melaporkan pengamatan yang serupa dalam penyelidikan mereka terhadap 27 pasien dengan pembedahan pada cedera mesenteric, 24 diantaranya (89\%) telah mendapatkan ekstravasasi kontras mesenteric vascular, sebuah perdarahan mesenteric atau kumpulan infiltrasi terkait dengan penebalan dinding usus, atau keduanya. Diagnosa CT dari perdarahan mesenteric yang aktif memerlukan suntikan bolus kontras IV (> 2,5 $\mathrm{mL} /$ detik) untuk mencapai peningkatan yang cukup dari pembuluh darah. Pendarahan mesenteric yang aktif membuat intervensi bedah diperlukan karena potensi kompromi vascular dari usus, bahaya pendarahan berlanjut, dan kemungkinan cedera dinding usus akut $[18,27]$.

Variasi dalam praktek dan teknik juga berpengaruh pada tanda spesifik dari cedera usus, keberadaan extraluminal gas. Pengamat kami mendeteksi extraluminal gas pada $32 \%$ dari pasien dengan cedera usus (Gambar. 2). Dengan pengecualian, tanda ini pada pengaturan pembedahan trauma tumpul abdomen. Meskipun kami telah mendapatkan beberapa kasus tanpa cedera dalam usus yang terdeteksi pengamat atau diduga udara bebas, semua kasus yang diawali oleh diagnosis peritoneal lavage, yang dikenal untuk menghasilkan cairan dan udara bebas pada rongga peritonium. Untungnya, penggunaan diagnostik peritoneal lavage adalah berkurang, 
dan prosedur ini hampir tidak memiliki peran dalam kestabilan hemodinamika pasien untuk mengevaluasi CT yang sedang dipertimbangkan. Meskipun Hamilton $\mathrm{dkk} .{ }^{28}$ melaporkan beberapa pasien dengan trauma tumpul abdominal dengan udara bebas pada abdomen tanpa cedera usus, dalam penghakiman mereka banyak kasus yang disalahtafsirkan dengan pneumothorax untuk pneumoperitoneum.

Tidak ada tanda individu CT yang dapat dianggap sensitif dan spesifik untuk cedera usus atau mesenterik. Bahkan sebelum menguji input nilai dari tanda-tanda ini, kami ingin membuktikan apakah radiologists dengan berbagai tingkat pengalaman dapat mencapai hasil yang baik. Seperti yang ditunjukkan pada Tabel 1, interobserver yang sangat baik untuk berbagai tanda individu CT pada cedera usus dan untuk diagnosis dari cedera usus atau organ solid. Di antara delapan kriteria individual CT untuk cedera usus, hanya keberadaan ileus yang gagal memenuhi standar tes kehandalan.

Kami telah terdorong dan agak terkejut bahwa residen radiologi dalam pelatihan akurasi diagnostik yang hampir sesuai dengan para supervisor fakultas mereka. Beberapa residen hanya mendapatkan 2 tahun pelatihan dan 2 bulan didedikasikan untuk rotasi CT tubuh. Tentu saja, pengajaran dalam interpretasi CT trauma sangat penting, dan semua residen pada program pelatihan radiologi bersifat mendidik dan menerima bahan-bahan tertulis instruksional yang diarahkan ke arah tujuan ini. Residen yang berpartisipasi dalam penyelidikan ini tidak mendapatkan pelatihan khusus. Fakultas tingkat abdominal radiologists cenderung mendiagnosa cedera usus dan mesenteric dengan akurasi yang lebih baik dan keyakinan dari kelompok residen. Namun, hanya untuk melakukan perforasi duodenal fakultas merekam akurasi peningkatan yang signifikan.

Jika tanda-tanda usus pathognomonic trauma yang terdeteksi dalam kasus minoritas, bagaimana radiologists membuat diagnosa akurat? Jelas, radiologists mengandalkan kombinasi CT temuan, setiap variabel memiliki kepekaan dan ketegasan. Fakultas radiologists bahkan menggunakan clues seperti pancreatic terkait atau ginjal lacerations mengenali dekat usus cedera.
Mesenterik infiltrasi dan cairan bebas intraperitoneal yang paling sering dikaitkan dengan tanda-tanda CT trauma usus. ${ }^{13-21}$ Cairan bebas tanpa sumber yang jelas (misalnya, hati atau limpa pengoyakan) telah lama dikenal sebagai petunjuk penting untuk usus atau cedera mesenteric. ${ }^{13-21,29-33}$ Berpengalaman pengamat telah belajar untuk mengabaikan kecil koleksi terpencil cairan panggul di perempuan usia reproduksi, tetapi yang lain cairan koleksi pengaturan yang trauma menjamin keterbukaan dekat. ${ }^{29-33}$ Intraperitoneal cairan koleksi yang terutama input dari usus atau mesenteric cedera adalah orang-orang di mesentery atau dinding usus itu sendiri. Sentinel yang menggumpal menjelaskan tanda relatif sangat heterogen attenuating dan cairan (bekuan darah) yang cenderung menumpuk di dekat tempat cedera. ${ }^{34}$ Interloop segitiga atau cairan koleksi atau bercoret, kabur dari infiltrasi mesentery juga bernada sangat trauma dari usus. ${ }^{15,29-33}$ (Figs. 1-3) . Sayangnya, dalam instruksi untuk pengamat kami, kami tidak akan meminta mereka untuk menentukan lokasi atau tampilan intraperitoneal koleksi cairan, sehingga kemampuan kami untuk menganalisis kehandalan individu dari beberapa tanda-tanda peresapan mesenteric atau lebam. Kami pengamat mesenteric terdeteksi infiltrasi di $68 \%$ dari kasus-kasus usus cedera, dan 23\% dari kasus-kasus lainnya cedera. Lainnya penyelidik lapor tinggi kepekaan dan ketegasan untuk menandatangani ini agak berbeda namun dalam definisi yang tepat. ${ }^{13,17-21,30}$ Rizzo dkk. ${ }^{17}$ ditemukan mesenteric infiltrasi atau perdarahan di 24 (86\%) dari 28 pasien dengan usus atau mesenteric cedera. Hagiwara $\mathrm{dkk}^{30}$ melaporkan bahwa bercoret mesenteric infiltrasi adalah 69\% 100\% sensitif dan spesifik untuk diagnosis dari usus perpecahan. Namun, Breen dkk. ${ }^{19}$ menemukan bahwa terpencil mesenteric streaking adalah kurang bermanfaat tanda (sensitivitas dari $77 \%$, kekhususan dari 44\%). Beberapa penyelidik telah dicatat yang warnanya merah coklat dan berkenaan dgn anak limpa lacerations jarang menyebabkan mesenteric koleksi darah ${ }^{11-21,30}$.

Bahan dinding usus, sebagai menemukan terpencil, merupakan hal yang kecil dalam nilai diagnosing usus cedera, kecuali di tempat yang jelas diagnosing substansial mural lebam. 
Penyebab lainnya membaur dan fokus dinding usus thickening dikenal termasuk shock usus, pola tersebar dari usus submucosal busung mucosal dan perangkat tambahan disebabkan hypovolemia atau proses reperfusion. ${ }^{35}$ Namun demikian, bahan dinding usus sudah umum (60\% dari 50 pasien) dan mencari simpangan penting. Breen dkk. [19] dihitung sebagai tanda ini memiliki sensitivitas $50 \%$ dan 84\% dari ketegasan atas dasar dari 12 pasien dengan usus cedera. Dinding usus dengan bahan aktif mesenteric infiltrasi atau pendarahan terutama adalah kombinasi umum dan penting dan telah diakui di $89 \%$ dari pasien yang telah operasi usus atau konfirmasi dari mesenteric cedera dilaporkan oleh Dowe dkk. ${ }^{18}$

Meskipun kami tidak termasuk tandatanda ini dalam penyelidikan kami, dan lainnya radiologic tanda-tanda klinis sangat terkait input dari cedera usus, termasuk gangguan yang melukai dinding abdominal otot (melukai burut) dan kursiecchymosis sabuk atau bruising dari dinding abdominal, khususnya pada anak-anak. ${ }^{36,37}$

CT akurat diagnosa dari usus cedera semakin penting karena sebagian besar anak-anak dan orang dewasa yang stabil hemodynamically sekarang dirawat nonoperatively, bahkan dengan CT bukti kuat dan hemoperitoneum-jeroan cedera. 3,7 Namun, transmural usus lacerations, mesenteric cedera aktif dengan darah (pendarahan), dan beberapa lainnya cedera usus dan mesenteric masih memerlukan operasi. ${ }^{8-10,18}$

Investigasi kami hanya terbatas pada gelar oleh retrospektif alam, yang kami percaya akan tidak dapat dihindari karena relatif keanehan dari usus cedera dan harus mengumpulkan jumlah kasus yang cukup untuk mencapai statistik signifikan. Namun, kami percaya bahwa kebanyakan biases diminimalkan karena kami telah disertakan dalam jumlah besar segala jenis cedera abdominal baik dalam studi perbandingan kelompok dan kelompok dan karena kita diuji radiologists sembilan, masing-masing dari mereka telah menyadarinya dari diagnosa dan jumlah usus kasus trauma. Kami juga melaporkan hasil calon interpretasi ini 112 CT ujian, di mana diagnosa dari cedera usus dibuat dengan akurasi $82 \%$, sensitivitas $64 \%$, dan ketegasan dari $97 \%$.

Potensial lainnya kritik dari investigasi kami kekhawatiran lainnya mungkin biases.
Banyak pasien yang telah cedera usus CT tidak ada evaluasi dan tidak, oleh karena itu, termasuk dalam belajar karena klinis jelas dan cedera parah memerlukan operasi mendesak. It would be praktis dan tidak etis untuk tunduk kepada pasien CT ini, sehingga kami adalah penduduk condong ke kurang usus cedera parah, meskipun ini pasien dengan luka parah kurang mencerminkan potensi calon CT. Apakah masuknya pasien dengan cedera parah usus akan mempengaruhi hasil kita tidak diketahui.

CT pengamat kami mungkin telah mengetahui bias oleh mereka yang berpartisipasi dalam studi radiologists kinerja dalam mendeteksi dan usus abdominal lainnya cedera pada CT dan yang telah dianjurkan untuk meninjau relevan trauma CT sastra. Namun, tidak ada persiapan khusus lainnya atau coaching diberikan. Selain itu, operator penerima karakteristik metodologi yang digunakan memungkinkan kami untuk menganalisa trade-off antara kepekaan dan ketegasan dari CT untuk mendeteksi dan kecenderungan menuju overinterpreting apapun yang mungkin dihasilkan dari juru bias.

\section{SIMPULAN}

Kami menyimpulkan bahwa usus mesenteric cedera dan tetap menjadi tantangan untuk mendiagnosa;bagaimanapun, radiologists dengan berbagai tingkat pengalaman dan keahlian dapat mencapai hasil yang akurat dan digandakan menggunakan berbagai kriteria CT.

\section{DAFTAR PUSTAKA}

1. Peitzman AB, Arnold SA, Boone DC. Trauma manual. Pittsburgh, PA: University of Pittsburgh Press, 1994:93

2. Buck G, Dalton $M$, Neely W. Diagnostic laparotomy for abdominal trauma. Am Surg 1986;52:41-43

3. Cox E. Blunt abdominal trauma: a 5 year analysis of 870 patients requiring celiotomy. Ann Surg 1984;199:467-474

4. Asbun $H$, Irani $H$, Roe $E$, et al. Intra-abdominal seatbelt injury. J Trauma 1990;30:189-193

5. Burney RE, Mueler GL, Coon WW, et al. Diagnosis of isolated small bowel injury following blunt abdominal trauma. Ann Emerg Med 1983; 12:71-74 
6. Donohue J, Crass R, Trunkey D. Management of duodenal and small intestinal injury. World J Surg 1985;9:904-913

7. Peitzman, AB, Makoroin MS, Slasky BS, Ritter P. Prospective study of $\mathrm{CT}$ in initial management of blunt abdominal trauma. J Trauma 1986;26:585-591 8. Roman E, Silva VS, Lucas C. Management of blunt duodenal injury. Surg ynecol Obstetn 1971;132:7-14

9. Snyder WH III, Weigelt JA, Watkins WL, Beitz DS. Surgical management of duodenal trauma. Arch Surg 1980;115:422-429

10. Lucas CE, Ledgerwood AM. Factors influencing outcome after blunt duodenal injury. J Trauma 1975;15:839-846

11. Tsang BD, Panacek EA, Brant WE, Wisner DH. Effect of oral contrast administration of abdominal computed tomography in the evaluation of acute blunt trauma. Ann Emerg Med 1997;30:7-13

12. Cook DE, Walsh JW, Vick CW, Brewer WH. Upper abdominal trauma: pitfalls in CT diagnosis. Radiology 1986;159:65-69

13. Donohue JH, Federle MP, Griffiths BG, Trunkey DD. Computed tomography in the diagnosis of blunt intestinal and mesenteric injuries. J Trauma 1987;27:11-17

14. Mirvis SE, Gens DR, Shanmuganathan K. Rupture of the bowel after blunt abdominal trauma: diagnosis with CT. AJR 1992;159:12171221

15. Nghiem HV, Jeffrey RB Jr, Mindelzun RE. CT of blunt trauma to the bowel and mesentery. AJR 1993;106:53-58

16. Janzen DL, Zwirewich CV, Breen DJ, Nagy A. Diagnostic accuracy of helical CT for detection of blunt bowel and mesenteric injuries. Clin Rad 1998;53:193-197

17. Rizzo MJ, Federle MP, Griffiths BG. Bowel and mesenteric injury following blunt abdominal trauma: evaluation with CT. Radiology 1989;173:413-148

18. Dowe MF, Shanmuganathan K, Mirvis SE, Steiner RC, Cooper C. CT findings of mesenteric injury after blunt trauma: implications for surgical intervention. AJR 1997;168:425-428

19. Breen DJ, Janzen DL, Zwirewich CV, Nagy AG. Blunt bowel and mesenteric injury: diagnostic perfor-
CT for Detection of Bowel Injuries AJR:176, January 2001135 mance of CT signs. J Comput Assist Tomogr 1997; 21:706-712

20. Levine $C D$, Gonzales RN, Wachsberg $\mathrm{RH}$, Ghanekar D. CT findings of bowel and mesenteric injury. J Comput Assist Tomogr 1997;21:974-979

21. Sherck J, Shatney C, Sensaki K, Selivanov V. The accuracy of computed tomography in the diagnosis of blunt small bowel perforation. Am J Surg 1994;168:670-675

22. Dorfman DD, Berbaum KS, Metz CE. Receiver operator characteristic rating analysis: generalization to

the population of readers and patients with the jackknife method. Invest Radiol 1992;27:723731

23. Cronbach LJ. Essentials of psychological testing, 4th ed. Philadelphia: Harper and Row. 1984:170

24. Federle MP, Peitzman A, Krugh J. Use of oral contrast material in abdominal trauma CT scans: is it dangerous. J Tauma 1995;38:37-53

25. Federle MP, Yagan N, Petizman AB, Krugh J. Abdominal trauma: use of oral contrast material for CT is safe. Radiology 1997;205:9193

26. Lim-Dunham JE, Narra J, Benya EC, Donaldson JS. Aspiration after administration of oral contrast material in children undergoing abdominal CT for trauma. AJR 1997;169:10151018

27. Jeffrey RB Jr, Cardoza JD, Olcott EW. Detection of active intraabdominal arterial hemorrhage: value ofdynamic contrast-enhanced CT. AJR 1991;156: 725-729

28. Hamilton P, Rizoli S, McLellan B, Murphy J. Significance of intra-abdominal extraluminal air detected by $\mathrm{CT}$ scan in blunt abdominal trauma. J Trauma 1995;39:331-333

29. Levine CD, Patel UJ, Wachsberg RH, Simmons MZ, Baker SR, Cho KC. CT in patients with blunt abdominal trauma: clinical significance of intraperitoneal fluid detected on a scan with otherwise normal findings. AJR 1995;164:1381-1385

30. Hagiwara A, Yukioka T, Satou M, et al. Early diagnosis of small intestine rupture from blunt abdominal trauma using computed 
tomography: significance of the streaky density within the mesentery. J Trauma 1995;38:630633

31. Hulka F, Mullins RJ, Leonardo V, Harrison MW, Silberberg $P$. Significance of peritoneal fluid as an isolated finding on abdominal computed tomographic scans in pediatric trauma patients. J Trauma 1998; 44:1069-1072

32. Cunnigham MA, Tyroch AH, Kaups KL, Davis JW. Does free fluid on abdominal computed tomographic scan after blunt trauma require laparotomy? J Trauma 1998;44:599-602

33. Brasel KJ, Olson CJ, Stafford RE, Johnson TJ. Incidence and significance of free fluid on abdominal computed tomographic scan in blunt trauma. J Trauma 1998;44:889-893

34. Orwig D. Federle MP. Localized clotted blood as evidence of visceral trauma on $\mathrm{CT}$ : the sentinel clot sign. AJR 1989;153:747-749

35. Mirvis SE, Shanmuganathan K, Erb R. Diffuse small-bowel ischemia in hypotensive adults after blunt trauma (shock bowel): CT findings and clinical significance. AJR 1994;163:13751379

36. Hayes CW, Conway WF, Walsh JW, et al. Seat belt injuries: radiologic findings and clinical correlation. RadioGraphics 1991;11:23-36

37. Strouse PJ, Close BJ, Marshall KW, Cywes R. CT of bowel and mesenteric trauma in children. RadioGraphics 1999;19:1237-1250 